\title{
Pengaruh Transformational Leadership terhadap Kinerja Karyawan dengan Innovative Behavior sebagai Variabel Mediator di BPJS Ketenagakerjaan
}

\author{
Aries Zetni Hydayati, Fendy Suhariyadi \\ Universitas Airlangga \\ e-mail: arieszetni@yahoo.com
}

\begin{abstract}
The purpose of this study is to analyse the effect of transformational leadership on performance with innovative behaviour as a medium variable in achieving sustainable competitive advantages, the effect of transformational leadership on employees' ability to innovate, the effect of employees' innovation skills on their performance and the effect of transformational leadership on employees' performance. The research approach uses quantitative technique. While data collection in this study is a survey method using Likert scale. The research data analysis will be using SEM analysis with SmartPLS version 3. The samples are 86 employees of membership section. Purposive sampling technique will be employed as samples fetching method. The results prove that there is a significant influence on transformational leadership style on employees' performance with their innovation behaviour as an intermediate variable. Impact of transformational leadership style is found on employees' innovation. There is an influence of employees' innovation behaviour on their performance. Significant influence of transformational leadership style appears on employees' performance.
\end{abstract}

Keywords: transformational leadership, innovation ability, employees' performance, BPJS Employment

\section{PENDAHULUAN}

BPJS Ketenagakerjaan yang ada sekarang ini merupakan transformasi dari PT Jamsostek (Persero). Perubahan atau transformasi PT Jamsostek (Persero) menjadi BPJS Ketenagakerjaan terbagi menjadi 3 fase. Tahun 2019 merupakan fase kritis ketiga. Fase kritis ketiga dimulai tahun 2015 sampai dengan 2025. Secara badan hukum terjadi perubahan badan hukum organisasi dari BUMN menjadi Badan Hukum Publik. Berdasarkan cakupan penanganan, BPJS dibagi menjadi 2 yaitu BPJS Kesehatan dan BPJS Ketenagakerjaan.

Transformasi BPJS Ketenagakerjaan lebih lanjut juga berdampak pada pertama perubahan cakupan kepesertaan wajib dari hanya Tenaga Kerja Penerima Upah menjadi perlindungan untuk seluruh pekerja. Kedua, perubahan peng- alihan wewenang pelaksanaan inspeksi kepatuhan kepesertaan dalam sistem penegakan hukum (law enforcement) dari Kementerian Tenaga Kerja kepada BPJS Ketenagakerjaan. Ketiga, perubahan program yang dikelola dari Jaminan Kecelakaan Kerja (JKK), Jaminan Hari Tua (JHT), Jaminan Kematian (JKM), dan Jaminan Pemeliharaan Kesehatan (JPK) menjadi Jaminan Kecelakaan Kerja (JKK), Jaminan Hari Tua (JHT), Jaminan Kematian (JKM), dan Jaminan Pensiun (JP). Ini berarti ada satu program yang tidak lagi menjadi program BPJS yaitu Jaminan Pemeliharaan Kesehatan (JPK) dan penambahan satu program baru yaitu Jaminan Pensiun.

Hilangnya program Jaminan Pemeliharaan Kesehatan yang dikelola BPJS Ketenagakerjaan, mengakibatkan BPJS Ketenagakerjaan kehilangan 3 triliun pendapatan iuran dalam setahun dari 
iuran program JPK secara nasional, karena dialihkan kepada BPJS Kesehatan. Kondisi ini memaksa organisasi untuk melakukan restrukturisasi bisnis dengan meningkatkan manfaat dan juga menambah program sehingga bisa mendapatkan pendapatan iuran secara signifikan. Khusus untuk jaminan pensiun merupakan strategi manajemen yang diajukan pada saat pembuatan draf Undang-Undang Sistem Jaminan Sosial Nasional dan juga Peraturan Pemerintah terkait Penyelenggaraan Program Jaminan Sosial Ketenagakerjaan akibat tidak adanya program Jaminan Pemeliharaan Kesehatan. Sehingga BPJS Ketenagakerjaan memungkinkan mendapatkan pendapatan iuran lain pengganti program Jaminan Pemeliharaan Kesehatan.

Upaya perubahan tentu tidak cukup dengan hanya menambah program. BPJS Ketenagakerjaan harus melakukan tidak hanya persiapan yang jauh lebih baik tetapi memerlukan transformasi mulai cara pandang, pola kerja sampai kepada model bisnis yang diterapkan secara menyeluruh melalui suatu penahapan yang terencana dengan baik dalam jangka waktu yang panjang. Regulasi pemerintah tentang penyelenggaraan sistem jaminan sosial ketenagakerjaan membuka tantangan bagi entitas ini untuk semakin harus memperhatikan performa kinerja organisasi. Salah satu parameter kinerja organisasi adalah pencapaian dana kelolaan.

Dana kelolaan dari waktu ke waktu menunjukkan adanya kenaikan. Pada tahun 2016 dana kelolaan menjadi 297 Triliun. Pada tahun 2017 dana kelolaan sebesar 320 Triliun. Dalam empat tahun BPJS Ketenagakerjaan berhasil menaikkan dana kelolaannya sebesar 214\%. Proyeksi Dana Investasi pada tahun 2018 adalah sebesar Rp 356 triliun, tahun 2019 sebesar Rp 415 triliun. (Laporan Road Map BPJS Ketanagakerjaan Tahun 2017-2021). Selain dana kelolaan, kinerja organisasi dapat diukur dari capaian jumlah perusahaan aktif yang menjadi peserta BPJS Ketenagakerjaan. Pada tahun 2016 perusahaan aktif yang menjadi peserta BPJS Ketenagakerjaan adalah 359.724. Pada tahun 2017 menjadi 455.090. Setelah mengalami transformasi menjadi BPJS Ketenagakerjaan berhasil menaikkan kepesertaan perusahaan aktif menjadi 240\%. (Laporan Tahunan 2013-2017 dan http://bi.bpjsketenagakerjaan.go.id). Ukuran kinerja ketiga di antaranya adalah perluasan jaringan operasi. Tahun 2016 adalah tahun perluasan jaringan operasi dengan adanya 53 Kantor Cabang Perintis dan 500 SPO bank kerjasama dan mulai dirintis e-business. Tahun 2017 adalah tahun pelayanan di mana sudah diimplementasikan Service Blue Print (SBP) dan Pelayanan Prima yang terdiri dari 3P: People, Process, dan Physical Evidence. BPJS Ketenagakerjaan juga sudah mengoptimalkan penerapan Service Level Agreement (SLA) untuk pelayanan di BPJS Ketenagakerjaan. SLA untuk JHT adalah tiga hari kerja, JKK 7 hari kerja, JKM tiga hari kerja dan JP adalah 15 hari kerja untuk JP berkala, untuk pengambilan selanjutnya per tanggal 1 bulan berikutnya sedangkan untuk JP lumpsum adalah dua hari kerja sehingga BPJS Ketenagakerjaan saat ini merupakan Badan Hukum Publik yang sedang bertransformasi menjadi service organization.

Pencapaian kinerja organisasi dan keberhasilan bertransformasi menjadi service organization ini tentunya perlu didukung oleh pencapaian kinerja di tingkat kantor cabang. Berdasarkan data internal BPJS Ketenagakerjaan, dari 16 Kantor Cabang di Wilayah Jawa Timur, Kantor Cabang Gresik merupakan cabang dengan kinerja paling rendah. Perusahaan menggunakan empat parameter Balance Score Card yaitu perspektif keuangan, kinerja pelanggan, proses bisnis internal, pertumbuhan, dan pembelajaran sebagai penilaian kinerja di tingkat unit. KPI 
unit Kantor Cabang Gresik masih fluktuatif. Di tahun 2015 mencapai skor 3,675, kemudian meningkat di tahun 2016 menjadi 4,719. Namun di tahun 2017 mengalami penurunan cukup tajam yaitu 1,386 dari skala 6. Penurunan kinerja unit tentu tidak terlepas dari keberadaan kinerja karyawan di tingkat unit tersebut. Jumlah karyawan kepesertaan di Unit Kabupaten Gresik ada 12 orang. Berdasarkan data KPI individual menunjukkan bahwa pencapaian kinerja kepesertaan karyawan tingkat individu di Kantor Cabang Gresik belum seluruhnya sesuai harapan yaitu mencapai kategori istimewa. Bahkan pada pencapaian tahun 2017 terdapat satu karyawan masih berkategori kurang, satu karyawan pada kategori cukup. Hasil selengkapnya dapat dilihat pada Tabel 1.

Karyawan yang memiliki kinerja individu yang tinggi bisa membuat kinerja unit tinggi, demikian pula sebaliknya. Kinerja karyawan yang kurang maksimal tentu tidak terlepas dari peran pimpinan. Seorang pemimpin harus mampu untuk mengoptimalkan kemampuan organisasi untuk belajar. Kemampuan mengoptimalkan tersebut bergantung pada gaya kepemimpinan yang dimiliki oleh pimpinan.
Gaya kepemimpinan transformasional, menurut Bass (1985) dalam Yukl (2005:305), adalah kepemimpinan yang membuat para pengikut merasakan kepercayaan, kekaguman, kesetiaan dan penghormatan kepada pemimpin, dan termotivasi untuk melakukan lebih daripada yang awalnya diharapkan oleh karyawan. Bass menambahkan bahwa pemimpin transformasional mengubah dan memotivasi para pengikut dengan cara membuat para karyawan lebih menyadari pentingnya hasil tugas, membujuk para karyawan untuk lebih mementingkan kepentingan tim atau organisasi dibandingkan kepentingan pribadi dan mengaktifkan kebutuhan mereka yang lebih tinggi. Kepemimpinan transformasional merupakan kepemimpinan yang mampu mendatangkan perubahan di dalam setiap individu yang terlibat atau bagi seluruh organisasi untuk mencapai kinerja yang lebih tinggi. Dengan kemampuan tersebut diharapkan kinerja karyawan BPJS Ketenagakerjaan yang mengedepankan konsep service organization akan lebih berhasil. Bass (1985) kepemimpinan transformasional merupakan salah satu metode terbaik untuk meningkatkan kinerja individu dan kelompok. Pemimpin transformasional memotivasi pengikut untuk menge-

Tabel 1

Kinerja Karyawan Kepesertaan BPJS Ketenagakerjaan Cabang Gresik 2015-2017

\begin{tabular}{|c|c|c|c|c|c|c|}
\hline Karyawan & 2015 & Kategori & 2016 & Kategori & 2017 & Kategori \\
\hline 1 & 3.81 & Baik & 2.43 & Kurang & 2.93 & Cukup \\
\hline 2 & 3.98 & Baik & 3.11 & Cukup & 3.00 & Cukup \\
\hline 3 & & & & & 2.26 & Kurang \\
\hline 4 & & & & & 2.19 & Kurang \\
\hline 5 & 2.50 & Cukup & 3.75 & Baik & 3.92 & Baik \\
\hline 6 & 2.31 & Kurang & 3.16 & Cukup & 3.24 & Baik \\
\hline 7 & 1.86 & Kurang & 2.93 & Cukup & 2.79 & Cukup \\
\hline 8 & 2.05 & Kurang & 3.41 & Baik & 3.38 & Baik \\
\hline 9 & 3.24 & Baik & 3.81 & Baik & 3.83 & Baik \\
\hline 10 & 3.65 & Baik & 2.66 & Cukup & 3.64 & Baik \\
\hline 11 & 1.95 & Kurang & 3.28 & Baik & 3.18 & Cukup \\
\hline 12 & & & 2.95 & Cukup & 3.08 & Cukup \\
\hline
\end{tabular}

Sumber: KPI BPJS Ketenagakerjaan KC Gresik 
rahkan dan mengeksplorasi prospek yang ada serta baru. kepemimpinan transformasional secara proaktif membantu para pengikut untuk mencapai tujuan dengan standar tinggi (Antonakis, Avolio, \& Sivasubramaniam, 2003). Pemimpin transformasional menggerakkan pengikut di luar kepentingan pribadi (Bass, 1999). Kepemimpinan transformasional menciptakan lingkungan di mana karyawan termotivasi dan berenergi (De Jong \& Bruch, 2013). Karyawan termotivasi yang bekerja dalam iklim yang mendukung memberikan layanan pelanggan yang lebih efektif, memperkuat kinerja organisasi.

Keterkaitan gaya kepemimpinan terhadap kinerja karyawan bergantung pada fase organisasi. Menurut Tierney (1999) hubungan antara atasan dan bawahan akan menghasilkan lebih banyak persepsi positif karyawan pada perubahan organisasi. Nadler, Thies, and Nadler (2001) menyatakan bahwa perubahan yang efektif, menuntut keterlibatan aktif pimpinan sebagai kepala arsitek dari proses perubahan. Pimpinan harus memiliki kompetensi organisasi. Pemimpin harus memastikan bahwa peserta merasa bagian dari pengambilan keputusan, terlibat dalam proses. Jika tidak dilibatkan maka anggota organisasi akan menjadi sinis dan tidak responsif, karyawan berpikir bahwa pemimpin membutuhkan karyawan hanya "lip service" untuk konsultasi tetapi tidak terjadi dalam kenyataan. Karisma seorang pimpinan harus divalidasi oleh pengikutnya. Pada konteks perubahan atau transformasi organisasi ini maka gaya kepemimpinan transformasional yang memotivasi karyawan, memberikan inspirasi serta memberikan daya karisma pada karyawan sangat diperlukan.

Pemimpin transformasional, karismatik, dan visioner dapat berhasil mengubah status quo dalam organisasi mereka dengan menampilkan perilaku yang tepat pada tahap yang tepat dalam proses transformasi. Ketika ada kesadaran bah- wa cara-cara lama tidak lagi bekerja, para pemimpin tersebut dapat melakukan pengembangan visi yang menarik untuk masa depan. Sebuah visi yang baik memberikan dampak strategis dan akan meningkatkan motivasi. Pernyataan yang jelas tentang tujuan organisasi akan menjadi sumber inspirasi dan komitmen karyawan (Eisenbach, Regina dkk. 1999). Pemimpin menjadi aktor perubahan yang dapat merakit dan memotivasi karyawan dengan kekuatan yang cukup untuk memimpin upaya perubahan (Kotter, 1995). Pemimpin Transformasional yang ingin melaksanakan perubahan manajemen harus berhati-hati untuk mencocokkan nilai-nilai yang dianut dan dilaksanakan. Mereka harus melakukan ini meskipun perubahan lingkungan organisasi terus menerus membuat kesesuaian tersebut sangat sulit (Eisenbach, Regina dkk. 1999).

Perubahan atau transformasi organisasi membawa reaksi yang berbeda-beda pada setiap karyawan, maka solusi dari managing change adalah dengan memfokuskan pada karyawan. Perubahan akan memengaruhi siapa pun baik pihak manajemen ataupun karyawan. Transformasi organisasi bisa ditanggapi dengan reaksi negatif (resistances) bergantung jenis dan derajat perubahan itu sendiri. Untuk mencapai keberhasilan suatu program perubahan maka setiap orang harus siap dan mampu mengubah perilakunya. Hal ini sangat bergantung pada apa yang memengaruhi perilaku dan apa pula yang mendorong seseorang untuk berubah (Mangkuprawira, 2009). Abram (2006) menjabarkan bahwa ada beberapa tipe psikologi manusia ketika terjadi perubahan organisasi yaitu: penolakan (denial), marah (anger), negosiasi (bargaining), depresi (depression) dan penerimaan (acceptance).

Pada tahun 2018 BPJS Ketenagakerjaan memasukkan Inovasi dalam item Pertumbuhan dan Pembelajaran di KPI Unit maupun KPI Individu. Hal ini dilakukan untuk meningkatkan perilaku 
inovatif untuk seluruh insan BPJS Ketenagakerjaan. Organisasi yang inovatif akan dapat merespons tantangan dengan cepat, dapat bertahan dan lebih mudah berkembang (Carmeli et al., 2006).

Pemimpin transformasional dikatakan memiliki pengaruh positif pada motivasi dan kapasitas untuk memunculkan perilaku inovasi melalui perilaku keteladanan, membangun kepercayaan, memberikan otonomi, melahirkan komitmen untuk visi inspirasional, dan mendorong pengikut untuk tidak terkungkung asumsi lama. Kepemimpinan transformasional telah berfokus pada melahirkan inovasi sebagai fungsi inti. Dukungan penelitian sebelumnya juga menyatakan bahwa peran pemimpin transformasional sebagai pendorong penting perilaku inovasi di berbagai fungsi dan tingkat organisasi (Lie et al., 2015).

Penelitian sebelumnya yang dilakukan Bass (1985), Basu \& Green (1997) Tichy \& Ulrich (1984) menunjukkan bahwa gaya kepemimpinan transformasional menentukan perilaku inovasi. Namun penelitian yang dilakukan Samad (2012) dengan judul "The Influence of Innovation and Transformational Leadership on Organizational Performance", menunjukkan hubungan antara inovasi, kepemimpinan transformasional dan kinerja organisasi. Studi ini menemukan baik kepemimpinan transformasional dan inovasi ditemukan memiliki pengaruh signifikan terhadap kinerja organisasi. Karyawan yang menghasilkan gagasan inovatif akan mampu membuat dirinya memiliki cara baru dan efektivitas untuk mencapai kinerja. BPJS Ketenagakerjaan mendorong inovasi karyawan. Karyawan yang memiliki ide baru akan mendapatkan reward dari perusahaan dan akan meningkatkan point penilaian kinerja melalui KPI. Beberapa karyawan yang memiliki kemampuan beride dan inisiatif menunjukkan semangat kerja yang tinggi dan kecepatan menyelesaikan pekerjaan dibandingkan karyawan minim ide dan inisiatif.

\section{KERANGKA KONSEPTUAL}

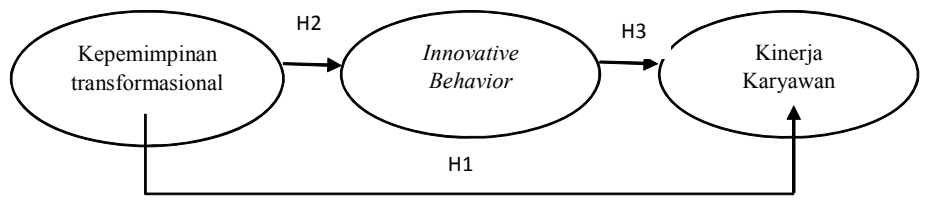

Gambar 1 Kerangka Konseptual Penelitian

\section{METODE PENELITIAN}

Pendekatan penelitian menggunakan kuantitatif. Metode pengumpulan data yang digunakan dalam penelitian ini adalah metode survey dengan menggunakan skala Likert. Analisis data pada penelitian ini akan menggunakan analisis SEM dengan smartPLS versi 3. Kepemimpinan transformasional didefinisikan sebagai pemimpin yang menginspirasi para pengikut untuk melampaui kepentingan pribadi mereka dan yang mampu membawa dampak mendalam dan luar biasa bagi pengikutnya. Dimensi-dimensi gaya kepemimpinan transformasional mengacu pada penelitian Bass dan Avolio (1994). Kemampuan inovasi adalah upaya yang dilakukan karyawan untuk menghasilkan dan mengimplementasi ide yang dimiliki pada organisasi. Indikator yang digunakan pada penelitian ini mengacu pada pendapat Scott and Bruce tahun 1994. Kinerja karyawan pada penelitian ini diukur dari key performance indicator karyawan kepesertaan BPJS. Sampel adalah karyawan Bidang Kepesertaan yang berjumlah 86 orang. Teknik Pengambilan sampel dengan teknik purposive sampling.

\section{HASIL PENELITIAN}

Jumlah responden dalam penelitian ini sebanyak 86 orang reponden yang terdiri atas lakilaki dan perempuan. Komposisi responden yang berjenis kelamin laki-laki dan perempuan hampir berimbang. Dominasi responden berjenis kelamin 
laki-laki yang berjumlah 46 orang $(53,5 \%)$, sementara perempuan berjumlah 40 orang $(46,5 \%)$. Usia responden yang paling muda adalah 24 tahun, kemudian yang paling tua 56 tahun. Rata-rata usia responden 34,38 tahun. Dengan standar deviasi 9,037 tahun. Kemudian lama kerja responden yang paling singkat 2 tahun dan yang paling lama 35 tahun. Rata-rata lama kerja responden 9,16 tahun dengan standar deviasi 7,938. Responden di bagian KBP ada 8 orang (9,3\%),di bagian KEP ada 66 orang atau $76,7 \%$ dan di bagian WAS ada 12 orang atau $14 \%$.

\section{Tahap Pengujian Measurement Model atau Outer Model}

\section{a. Uji Validitas}

Berikut hasil uji validitas konvergen, konstruk, dan diskriminan selengkapnya.

Tabel 2

Hasil Pengujian Validitas Konvergen, Konstruk dan Diskriminan

\begin{tabular}{lccccc}
\hline \multicolumn{3}{c}{ Indikator } & $\begin{array}{c}\text { Validitas } \\
\text { Konvergen }\end{array}$ & $\begin{array}{c}\text { Validitas } \\
\text { Konstrak }\end{array}$ & \multicolumn{3}{c}{ Validitas Diskriminan } \\
\cline { 2 - 6 } $\begin{array}{c}\text { Factor } \\
\text { Loading }\end{array}$ & AVE & \multicolumn{2}{c}{ Cross Loading } \\
\hline Kepemimpinan & Transformasional & & & \\
Leadership1 & 0.869 & 0.810 & 0.558 & 0.869 & 0.774 \\
Leadership2 & 0.918 & & 0.783 & 0.918 & 0.796 \\
Leadership3 & 0.931 & & 0.719 & 0.931 & 0.768 \\
Leadership4 & 0.911 & & 0.723 & 0.911 & 0.734 \\
Leadership5 & 0.913 & & 0.737 & 0.913 & 0.770 \\
Leadership6 & 0.934 & & 0.726 & 0.934 & 0.784 \\
Leadership7 & 0.889 & & 0.737 & 0.889 & 0.773 \\
Leadership8 & 0.914 & & 0.696 & 0.914 & 0.804 \\
Leadership9 & 0.903 & & 0.735 & 0.903 & 0.734 \\
Leadership10 & 0.862 & & 0.635 & 0.862 & 0.719 \\
Leadership11 & 0.829 & & 0.597 & 0.829 & 0.647 \\
Leadership12 & 0.923 & & 0.743 & 0.923 & 0.774 \\
Inovasi karyawan & & & & & \\
Inovasi01 & 0.979 & 0.927 & 0.847 & 0.837 & 0.979 \\
Inovasi02 & 0.972 & & 0.813 & 0.799 & 0.972 \\
Inovasi03 & 0.970 & & 0.861 & 0.817 & 0.970 \\
Inovasi04 & 0.956 & & 0.842 & 0.798 & 0.956 \\
Inovasi05 & 0.979 & & 0.831 & 0.823 & 0.979 \\
Inovasi06 & 0.921 & & 0.661 & 0.788 & 0.921 \\
Kinerja & & \multirow{2}{*}{1.000} & 1.000 & 0.780 & 0.843 \\
SKOR KPI & 1.000 & & & & \\
\hline
\end{tabular}

Sumber: Hasil olah Smart PLS
Pada perhitungan validitas konvergen, hasil perhitungan menunjukkan untuk seluruh variabel menunjukkan seluruh itemnya memiliki nilai factor loading lebih dari 0,5. Dengan hasil ini maka item seluruh variabel valid. Khusus untuk variabel kinerja hanya diukur dengan satu indikator laten, sehingga bernilai 1. Perhitungan validitas konstrak, hasil perhitungan menunjukkan seluruh konstrak variabel penelitian menunjukkan semua variabel memiliki nilai AVE lebih dari 0,5. Dengan hasil ini maka seluruh variabel laten memiliki kecukupan validitas yang baik. Perhitungan validitas diskriminan yang diukur dengan cross loading, menunjukkan hasil valid. Item pada masing-masing variabel memiliki nilai yang lebih besar dibandingkan kolom pada variabel lain. Dengan demikian, konstrak laten memprediksi indikator pada blok mereka lebih baik dibandingkan dengan indikator di blok yang lain.

\section{b. Reliabilitas}

Reliabilitas konstruk yang diukur dengan nilai cronbach alpha dan composite reliability, konstruk reliabel jika nilai composite reliability di atas 0,70 maka indikator disebut konsisten dalam mengukur variabel latennya. Berikut hasil selengkapnya.

Tabel 3

Hasil Pengujian Reliability Konstrak

\begin{tabular}{lcc}
\hline \multicolumn{1}{c}{ Variabel } & $\begin{array}{c}\text { Cronbach's } \\
\text { Alpha }\end{array}$ & $\begin{array}{c}\text { Composite } \\
\text { Reliability }\end{array}$ \\
\hline Kinerja & 1.000 & 1.000 \\
Leadership & 0.979 & 0.981 \\
Inovasi Karyawan & 0.984 & 0.987 \\
\hline
\end{tabular}

Sumber: Hasil olah Smart PLS

Hasil pengujian menunjukkan bahwa konstruk (variabel) seluruh variabel memiliki nilai 
composite reliability lebih besar dari 0,7 sehingga reliabel.

\section{Tahap Structural Model atau Inner Model}

Berikut adalah nilai estimate dari masingmasing hubungan antar-variabel penelitian.

Tabel 4

Nilai Koefisien Estimate Antar-Variabel

\begin{tabular}{cccc}
\hline Hubungan Antar-Variabel & Koefisien & t Statistics & P Values \\
\hline \multicolumn{4}{c}{ Pengaruh Langsung } \\
Leadership $\rightarrow$ Kinerja & 0.240 & 2.278 & 0.000 \\
Leadership $\rightarrow$ Inovasi & 0.842 & 23.098 & 0.000 \\
\hline Hubungan Antar-Variabel & Koefisien & $\mathrm{t}$ Statistics & P Values \\
\hline Inovasi $\rightarrow$ Kinerja & 0.641 & 5.702 & 0.023 \\
Pengaruh Tidak Langsung \\
Leadership $\rightarrow$ Inovasi $\rightarrow$ Kinerja & 0.539 & 5.582 & 0.040 \\
\hline
\end{tabular}

Sumber: Hasil olah Smart PLS

Hasil perhitungan menunjukkan arah koefisien pengaruh antar-variabel bernilai positif. Ini menunjukkan bahwa hubungan gaya kepemimpinan transformasional yang semakin baik akan membuat inovasi karyawan meningkat. Demikian juga gaya kepemimpinan transformasional yang semakin baik akan membuat kinerja karyawan meningkat. Inovasi karyawan yang semakin meningkat akan membuat karyawan meningkat.

Hasil pengujian hipotesis menunjukkan sebagai berikut.

1. Hipotesis penelitian pertama menyatakan: "Kepemimpinan transformasional berpengaruh pada kinerja karyawan”. Hasil perhitungan diperoleh nilai $\mathrm{t}$ statistik 5.702 dengan $\mathrm{p}$ value $0,000(\mathrm{p}<0,05)$. Karena $\mathrm{p}$ value kurang dari 0,05 maka hipotesis penelitian pertama diterima kebenarannya.

2. Hipotesis penelitian kedua menyatakan: "Kepemimpinan transformasional berpengaruh pada inovasi karyawan”. Hasil perhitungan diperoleh nilai $\mathrm{t}$ statistik 23.098 dengan $\mathrm{p}$ value $0,000(p<0,05)$. Karena $\mathrm{p}$ value kurang dari 0,05 maka hipotesis penelitian kedua diterima kebenarannya.

3. Hipotesis penelitian ketiga menyatakan: "Inovasi karyawan berpengaruh pada kinerja karyawan". Hasil perhitungan diperoleh nilai t statistik 2.278 dengan $\mathrm{p}$ value 0,023 ( $\mathrm{p}<$ $0,05)$. Karena $\mathrm{p}$ value kurang dari 0,05 maka hipotesis penelitian ketiga diterima kebenarannya.

Pengaruh tidak langsung pada penelitian ini juga dapat diketahui langsung berdasarkan hasil perhitungan SmartPLS versi 3 Profesional. Berdasarkan hasil perhitungan diperoleh nilai signifikansi 0,040. Nilai ini lebih kecil dari 0,05 yang berarti inovasi karyawan berperan sebagai mediasi kepemimpinan transformasional dengan kinerja karyawan. Atau dengan kata lain ada pengaruh tidak langsung kepemimpinan transformasional terhadap kinerja karyawan melalui inovasi karyawan. Dengan hasil ini maka peran mediasi inovasi karyawan adalah parsial mediasi. Parsial mediasi ini disebabkan kepemimpinan transformasional bisa langsung berpengaruh terhadap kinerja karyawan namun juga bisa berpengaruh tidak langsung terhadap kinerja melalui inovasi karyawan.

Penelitian ini juga memperoleh hasil besarnya pengaruh yang dapat dilihat dari nilai $\mathrm{R}$ Square. Nilai $\mathrm{R}^{2}$ menjelaskan seberapa besar variabel eksogen (independen/bebas) pada model mampu menerangkan variabel endogen (dependen/terikat). Nilai R square pada hubungan antarvariabel di atas menunjukkan sebagai berikut.

a. Pengaruh transformasional leadership berpengaruh terhadap inovasi karyawan sebesar 0,708 atau $70,8 \%$. Ini berarti perubahan inovasi karyawan yang disebabkan oleh adalah gaya kepemimpinan transformasional adalah $70,8 \%$. 
b. Pengaruh transformasional leadership dan inovasi karyawan berpengaruh terhadap kinerja karyawan sebesar 0,728 atau $72,8 \%$. Ini berarti perubahan kinerja karyawan yang disebabkan oleh adalah gaya kepemimpinan transformasional dan inovasi karyawan adalah $72,8 \%$.

Fit model dapat dianalisis dengan menggunakan beberapa hal berikut.

1. Nilai predictive relevance atau nilai Q-square. Hasil dari perhitungan Q-square dapat dilihat bahwa nilai Q-square sebesar 0,920576. karena nilai Q2 > 0, dapat disimpulkan bahwa hubungan antar-variabel memiliki tingkat prediksi yang baik.

2. Goodness of Fit (GoF). Nilai GOF adalah 0.8094. Menurut Tenenhau (2004), nilai GoF small $=0,1$, GoF medium $=0,25$ dan GoF besar $=0,38$. Dengan nilai GoF 0,8094 maka fit model termasuk yang besar karena melebihi 0,38 .

\section{DISKUSI}

Pengaruh Kepemimpinan Transformasional Terhadap Kinerja Karyawan

Sebagaimana yang dinyatakan oleh Bass, (1985) kepemimpinan transformasional adalah salah satu metode terbaik untuk meningkatkan kinerja individu dan kelompok, ternyata pada penelitian ini berkorelasi signifikan. Hasil penelitian diperoleh nilai koefisien bertanda positif sebesar 0,240. Yang berarti semakin baik gaya kepemimpinan transformasional maka semakin tinggi kinerja karyawan. Hasil perhitungan dengan uji t menunjukkan bahwa arah hubungan dan besarnya hubungan tersebut signifikan. Arti dari signifikan adalah dampak kepemimpinan transformasional pada kinerja adalah nyata. Berdasarkan dari data deskriptif menunjukkan bahwa gaya kepemimpinan transformasional pim- pinan BPJS Ketenagakerjaan di beberapa cabang adalah mendekati skor rata-rata 4. Yang berarti karyawan menilai gaya kepemimpinan transformasional yang dimiliki kepala cabang baik. Ini juga berarti kepala cabang BPJS Ketenagakerjaan di beberapa kota tersebut mampu memengaruhi bawahan, menstimulasi intelektual bawahan, memotivasi bawahan dan memberikan perhatian kepada karyawan.

Hasil penelitian ini sejalan dengan pernyataan teoretis yang menyatakan bahwa kepemimpinan transformasional (TL) memainkan peran penting dalam kinerja organisasi. Sebagaimana dinyatakan oleh Bass, (1985) kepemimpinan transformasional adalah salah satu metode terbaik untuk meningkatkan kinerja individu dan kelompok. Pemimpin transformasional memotivasi pengikut untuk mengerahkan dan mengeksplorasi prospek yang ada serta baru. Pemimpin transformasional secara proaktif membantu para pengikut untuk mencapai tujuan dengan standar tinggi (Antonakis, Avolio, \& Sivasubramaniam, 2003). Pemimpin transformasional menggerakkan pengikut di luar kepentingan pribadi langsung (Bass, 1999). Kepemimpinan transformasional menciptakan lingkungan di mana karyawan termotivasi dan berenergi (De Jong \& Bruch, 2013). Karyawan termotivasi yang bekerja dalam iklim yang mendukung memberikan layanan pelanggan yang lebih efektif, memperkuat kinerja organisasi (Giroux \& McLarney, 2014).

Pada saat pimpinan memberikan perhatian khusus terhadap kebutuhan masing-masing pengikut yang sangat penting untuk pertumbuhan dan pencapaian mereka (Bass \& Avolio, 1990). Kemudian pada saat pimpinan memberikan umpan balik positif kepada karyawan akan memotivasi mereka untuk menunjukkan lebih banyak upaya sehingga bisa mencapai kinerja optimal. Oleh karena itu, karyawan cenderung berperi- 
laku sedemikian rupa sehingga menyederhanakan kinerja tugas tingkat tinggi. Selain itu, pemimpin transformasional mendorong karyawan untuk lebih mempertimbangkan keuntungan kolektif dari organisasi dan pemimpin atas kepentingan pribadi (Bass, 1985). Pemimpin transformasional dengan hasil idealized influence yang tinggi akan memengaruhi kinerja pengikut dengan mengembangkan ikatan yang kuat dengan pengikut (Wang et al., 2008; Wang et al., 2005). Hasil penelitian ini menguatkan penelitian sebelumnya yang dilakukan oleh Samad (2012) yang bahwa kepemimpinan transformasional telah secara signifikan meningkatkan kinerja organisasi di perusahaan logistik Malaysia. Demikian juga penelitian Arif dan Akram (2018) yang menyatakan bahwa kepemimpinan transformasional dan kinerja organisasi memiliki hubungan yang kuat.

\section{Pengaruh Kepemimpinan Transformasional Ter- hadap Inovasi Karyawan}

Sebagaimana yang dinyatakan oleh Jannex, (2006) khususnya kepemimpinan transformasional sangat penting dalam upaya mengaktifkan kemampuan inovatif pengikutnya, ternyata pada penelitian ini berkorelasi signifikan. Hasil penelitian diperoleh nilai koefisien bertanda positif sebesar 0,842 . Yang berarti semakin baik gaya kepemimpinan transformasional maka semakin tinggi kemampuan karyawan dalam berinovasi. Hasil perhitungan dengan uji t menunjukkan bahwa arah hubungan dan besarnya hubungan tersebut signifikan. Arti dari signifikan adalah dampak kepemimpinan transformasional terhadap inovasi karyawan adalah nyata. Berdasarkan dari data deskriptif menunjukkan bahwa inovasi karyawan BPJS Ketenagakerjaan di beberapa cabang adalah melebihi dari skor 4. Yang berarti karyawan dinilai pimpinan memiliki kemampuan inovasi yang tinggi. Kemampuan inovasi tersebut di antara mencari proses atau cara baru, menghasilkan ide, memunculkan ide, mencari dan memastikan sumber dana untuk mengimplementasikan ide. Kemampuan inovasi karyawan yang kurang adalah dalam hal mengembangkan rencana dan jadwal untuk mengimplementasikan ide baru. Kemampuan yang rendah ini disebabkan karyawan lebih banyak terlibat pada tugas harian kantor yang relatif ketat sehingga sulit membuat rencana dan jadwal untuk mengimplementasikan ide baru.

Adanya pengaruh kepemimpinan transformasional terhadap inovasi sesuai dengan beberapa pernyataan bahwa kepemimpinan khususnya kepemimpinan transformasional sangat penting dalam upaya mengaktifkan kemampuan inovatif pengikut (Jennex, 2006). Karakteristik dan gaya kepemimpinan pemimpin adalah penentu utama kemampuan inovatif dalam organisasi. Literatur mengungkapkan bahwa gaya transformasional lebih cenderung mendorong inovasi organisasi daripada gaya transaksional (Xenikou, 2017).

Adanya pengaruh pemimpin transformasional terhadap inovasi ini dapat dijelaskan dengan argumen bahwa kepemimpinan transformasional siap membuat kelompok dan melengkapi bawahan dengan kekuatan, kepemimpinan, dan tentu saja mereka untuk membuat kemajuan dan mendorong untuk terus melakukan pembelajaran (Berson, Nemanich, Waldman, Galvin, \& Keller, 2006). Dengan konsep ini maka karyawan atau bawahan akan dapat menemukan ideide baru dari proses pembelajaran dan dukungan motivasi atasan. Hasil penelitian ini sejalan dengan penelitian García-Morales, Jiménez-Barrionuevo, dan Gutiérrez-Gutiérrez (2012) bahwa kepemimpinan transformasional berpengaruh pada kemampuan inovasi. Jung, Chow, \& Wu, (2003) menyatakan bahwa kepemimpinan transformasional memiliki hubungan positif dengan 
kemampuan inovasi di banyak perusahaan. Menurut Jung, Chow, \& Wu, (2003) kemampuan inovasi yang diberikan oleh pemimpin transformasional dengan menggunakan faktor-faktor motivasi untuk mengangkat kemampuan inovasi karyawan.

\section{Pengaruh Kemampuan Inovasi Terhadap Kinerja Karyawan}

Hasil penelitian yang dilakukan oleh Samad (2012) menyatakan bahwa inovasi berdampak pada kinerja memiliki korelasi yang signifikan dengan penelitian ini. Hasil penelitian diperoleh nilai koefisien bertanda positif sebesar 0,641. Yang berarti semakin tinggi kemampuan inovasi maka semakin tinggi kinerja karyawan. Hasil perhitungan dengan uji $\mathrm{t}$ menunjukkan bahwa arah hubungan dan besarnya hubungan tersebut signifikan. Arti dari signifikan adalah dampak inovasi karyawan terhadap kinerja adalah nyata. Berdasarkan dari data deskriptif menunjukkan bahwa inovasi karyawan BPJS Ketenagakerjaan di beberapa cabang adalah melebihi dari skor 4 . Yang berarti karyawan dinilai pimpinan memiliki kemampuan inovasi yang tinggi. Demikian juga pencapaian kinerja karyawan berdasarkan skor KPI adalah 3,8030. Ini berarti kinerja karyawan masih termasuk tinggi. Pencapaian 3,8030 adalah rata-rata KPI dari 86 karyawan. Dengan hasil yang signifikan berarti jika inovasi tinggi maka KPI juga tinggi dan sebaliknya. Meskipun secara rata-rata tidak tergambar pola hubungan inovasi dan kinerja namun hasil yang signifikan cukup menjelaskan bahwa jika inovasi karyawan tinggi maka kinerja karyawan baik, dan sebaliknya jika inovasi karyawan relatif kurang maka kinerja karyawan juga kurang baik. (Hasil hubungan tiap karyawan dapat dilihat di lampiran). Hasil penelitian ini menegaskan apa yang ada dalam latar belakang bahwa inovasi merupakan hal yang penting bagi kinerja karyawan. Sehingga untuk mengangkat kinerja karyawan yang masih kurang salah satunya adalah menggerakkan kemampuan inovasi karyawan oleh pimpinan cabang.

Adanya pengaruh inovasi terhadap kinerja ini dapat dijelaskan dengan argumen bahwa inovasi akan menghasilkan sumber daya baru, berharga, langka, dan tak dapat ditiru yang akan membuat karyawan tersebut dihargai dan mendapatkan perhatian pihak manajemen bahkan reward. Kondisi ini akan memacu karyawan tersebut menghasilkan kinerja yang lebih tinggi. Inovasi mengarah pada pengayaan sumber daya strategis perusahaan dan keunggulan kompetitif berkelanjutan sebagai aspek penting untuk mencapai kinerja organisasi. Inovasi yang berhasil dibuat oleh masing-masing individu akan membuat unit organisasi kaya akan temuan dan selanjutnya akan membuat faktor pembeda dari unit organisasi yang lain. Hasil penelitian yang menguatkan hubungan kemampuan inovasi pada kinerja adalah penelitian yang dilakukan Samad (2012). Hasil penelitian menunjukkan bahwa inovasi berdampak pada kinerja. Penelitian yang dilakukan Samad dilakukan pada konteks kinerja organisasi sedangkan pada penelitian ini berfokus pada kinerja individu.

\section{Pengaruh Kepemimpinan Transformasional Terhadap Kinerja Karyawan dengan Perilaku Inovasi sebagai Variabel Antara}

Sebagaimana yang dinyatakan oleh Byars dan Rue (2000:276) yang menyatakan bahwa faktor individu memengaruhi kinerja dan pada penelitian ini berpengaruh signifikan. Hasil penelitian diperoleh nilai koefisien bertanda positif sebesar 0,539. Yang berarti semakin baik gaya kepemimpinan transformasional maka semakin tinggi kemampuan karyawan dalam berinovasi 
dan berdampak signifikan terhadap peningkatan kinerja karyawan. Hasil perhitungan dengan uji t menunjukkan bahwa arah hubungan dan besarnya hubungan tersebut signifikan. Arti dari signifikan adalah dampak kepemimpinan transformasional pada kinerja dengan perilaku inovasi sebagai variabel antara adalah nyata. Berdasarkan dari data deskriptif menunjukkan bahwa gaya kepemimpinan transformasional pimpinan BPJS Ketenagakerjaan di beberapa cabang adalah mendekati skor rata-rata 4. Yang berarti karyawan menilai gaya kepemimpinan transformasional yang dimiliki kepala cabang baik. Ini juga berarti kepala cabang BPJS Ketenagakerjaan di beberapa kota tersebut mampu memengaruhi bawahan, menstimulasi intelektual bawahan, memotivasi bawahan dan memberikan perhatian kepada karyawan.

Hasil penelitian ini sejalan dengan pernyataan teoretis yang menyatakan bahwa kepemimpinan transformasional (TL) memainkan peran penting dalam kinerja organisasi. Kepemimpinan khususnya kepemimpinan transformasional sangat penting dalam upaya mengaktifkan kemampuan inovatif pengikut (Jennex, 2006). Karakteristik dan gaya kepemimpinan pemimpin adalah penentu utama kemampuan inovatif dalam organisasi. Literatur mengungkapkan bahwa gaya transformasional lebih cenderung mendorong inovasi organisasi daripada gaya transaksional (Xenikou, 2017).

Pemimpin transformasional siap membuat kelompok dan melengkapi bawahan dengan kekuatan, kepemimpinan, dan tentu saja mereka untuk membuat kemajuan dan mendorong untuk terus melakukan pembelajaran (Berson, Nemanich, Waldman, Galvin, \& Keller, 2006). Dengan konsep ini maka karyawan atau bawahan akan dapat menemukan ide-ide baru dari proses pembelajaran dan dukungan motivasi atasan. García-Morales, Jiménez-Barrionuevo, dan Guti-
érrez-Gutiérrez (2012) telah melakukan penelitian di 168 Perusahaan Spanyol untuk mengidentifikasi dampak kepemimpinan transformasional pada kemampuan inovasi. Jung, Chow, \& Wu, (2003) menyatakan bahwa kepemimpinan transformasional memiliki hubungan positif dengan kemampuan inovasi di banyak perusahaan. Menurut Jung, Chow, \& Wu, (2003) kemampuan inovasi yang diberikan oleh pemimpin transformasional dengan menggunakan faktor-faktor motivasi untuk mengangkat kemampuan inovasi karyawan.

\section{KESIMPULAN}

Berdasarkan dari hasil penelitian yang sudah dilakukan pada 86 karyawan di 7 cabang BPJS Ketenagakerjaan Kantor Cabang Surabaya Raya, Sidoarjo dan Gresik yang diolah dengan program SEM SmartPLS 3 menghasilkan kesimpulan sebagai berikut.

1. Ada pengaruh signifikan terhadap gaya kepemimpinan transformasional terhadap kinerja karyawan dengan perilaku karyawan dalam berinovasi sebagai variable antara. Semakin baik gaya kepemimpinan transformasional, maka semakin tinggi kinerja dan perilaku karyawan dalam berinovasi.

2. Ada pengaruh gaya kepemimpinan transformasional terhadap inovasi karyawan. Semakin baik gaya kepemimpinan transformasional maka semakin tinggi perilaku karyawan dalam berinovasi. Dengan hasil ini maka hipotesis penelitian kedua diterima kebenarannya.

3. Ada pengaruh perilaku inovasi karyawan terhadap kinerja karyawan. Semakin tinggi inovasi karyawan maka semakin tinggi kinerja karyawan. Dengan hasil ini maka hipotesis penelitian ketiga diterima kebenarannya.

4. Ada pengaruh signifikan gaya kepemimpinan transformasional terhadap kinerja karyawan. 
Semakin baik gaya kepemimpinan transformasional maka semakin tinggi kinerja karyawan. Dengan hasil ini maka hipotesis penelitian pertama diterima kebenarannya.

\section{SARAN}

Perlu dilakukan kajian lebih lanjut terkait kinerja organisasi setelah dilakukan penelitian pada kinerja individu. Apakah kinerja individu berkaitan atau berkorelasi pada kinerja unit atau organisasi. Serta kaitan inovasi individu pada kinerja organisasi. Sedangkan bagi perusahaan diharapkan perusahaan dapat terus mendorong kemampuan inovasi karyawan. Hal yang dapat dilakukan untuk mendorong hal tersebut adalah memberi reward atau penghargaan pada karyawan yang menghasilkan inovasi sesuai bidangnya. Kemudian melakukan coaching atau mentoring pada karyawan yang kurang dalam berinovasi. Gaya kepemimpinan transformasional juga terbukti berdampak pada kinerja dan inovasi karyawan. Sehingga perusahaan dapat memilih kepala cabang yang memiliki kemampuan transformasional dengan baik. Sehingga gaya bisa menjadi salah satu tolak ukur penempatan dan seleksi pimpinan cabang BPJS Ketenagakerjaan.

\section{DAFTAR RUJUKAN}

Abrahamson, E. 2000. Change without Pain, 7579. Harvard Business Review.

Antonakis, J., Avolio, B.J., \& Sivasubramaniam, N. 2003. Context and Leadership: An Examination of the Nine-Factor Full Range Leadership Theory Using the Multifactor Leadership Questionnaire. The Leadership Quarterly, 14, 261-295.

Baird, Lloyd. 1986. Managing Performance. New York: John Wileyd Son, Inc.
Bass, B.M. and Avolio, B.J. 1990. The Implications of Transactional and Transformational Leadership for Individual, Team and Organizational Development. Research in Organizational Change and Development, 4: 231-272.

Bass, B.M. \& Avolio, B.J. 1994. Improving Organizational Effectiveness through Transformational Leadership. Thousand Oaks, CA: Sage.

Bass, B.M. 1990. From Transactional to Transformational Leadership: Learning to Share the Vision'. Organizational Dynamics, 18, pp. 19-31.

Bass, B.M. 1985. Leadership: Good, Better, Best. Organizational Dynamics.

Bass, B.M., Avolio, B.J., \& Jung, D.I. 1999. ReExamining the Components of Transformational and Transactional Leadership using the Multifactor Leadership. Journal of Occupational and Organizational Psychology, 72, 441-462.

Basu, R. \& Green, S.G. 1997. Leader-Member Exchange and Transformational Lleadership: An Empirical Examination of Innovative Behaviors in Leader-Member Dyads. Journal of Applied Social Psychology, 27, 477-499.

Bernardin, H.J. \& Russel, J.E.A. 1993. Human Resource Management an Experiential Approach. Singapore: Mc Graw-Hill, Inc.

Berson, Y., Nemanich, L.A., Waldman, D., Galvin, B.M., \& Keller, R.T. 2006. Leadership and Organizational Learning: A Multiple Levels Perspective. Leadership Quarterly, 17(6), 577-594.

Burns, J.M. 1978. Leadership. New York: Harper Row.

Byars, L. Lloyd dan Rue, W. Leslie. 2000. Human Resource Management, International Edition. 6th Edition. McGraw-Hill. 
Carrel, et al. 1992. Organizational Behavior. Prentice Hall Inc.

Chin, W.W. 1998. The Partial Least Squares Approach for Structural Equation Modeling in G.A. Marcoulides (Ed.). Modern Methods for Business Research (pp.295-236). London: Lawrence Erlbaum Associates.

Jong, De \& Kemp, R. 2003. Determinants of CoWorkers' Innovative Behaviour: An Investigation into Knowledge Intensive Service. International Journal of Innovation Management. 7(2).

De Jong, J., \& Den Hartog, D. 2007. How Leaders Influence Employees' Innovative Behavior. European Journal of Innovation Management, 10(1), 41-64.

Desplaces, David. 2005. A Multilevel Approach to Individual Readiness to Change. The Journal of Behavioral and Applied Management, Vol.7, No.1.

Dorfman, P.W. and J.P. Howell. 1996. Dimensions of National Culture and Effective Leadership Patterns: Hofstede Revisited. Advances in International Comparative Management (3) pp.127-150.

Dyer, J., Gregersen, H., \& Christensen, C.M. 2011. The Innovator's DNA: Mastering the Five Skills of Disruptive Innovators. Harvard Business Press.

Eisenbach,Regina et al. 1999. Transformational Leadership in the Context of Organizational Change. Journal of Organizational Change Management, Vol. 12, No. 2, pp. 80-88.

Francoise Contreras, Juan C. Espinosa, Utz Dornberger, \& Yonni Angel Cuero Acosta. 2017. Leadership and Employees' Innovative Work Behavior: Test of a Mediation and Moderation Model. Asian Social Science; Vol. 13, No. 9.

Feldman, M.S. \& Pentland, B.T. 2003. Reconceptualizing Organizational Routines as a
Source of Flexibility and Change. Administrative Science Quarterly, 48, 94-118.

García-Morales, Jiménez-Barrionuevo, dan Gutiérrez-Gutiérrez. 2012. Transformational Leadership Influence on Irganizational Performance through Organizational Learning and Innovation. Journal of Business Research, 65(7), 1040-1050.

George, J.M. and Brief, A.P. 1992. Feeling GoodDoing Good: A Conceptual Analysis of the Mood at Work-Organizational Spontaneity Relationship. Psychological Bulletin, 112, 310-329.

Getz, I. \& Robinson, A.G. 2003. Innovative or Die: is that a Fact? Creativity Innovation Manage, 12( 3),130-136.

Ghozali, Imam. 2006. Aplikasi Analisis Multivariate dengan Program SPSS. (Edisi ke-4). Semarang: Badan Penerbit Universitas Diponegoro.

Ghiselli and Brown. 1995. Personnel and Industrial Psychology. New York: Mc. Graw Hill Book Company Inc.

Gibson, Ivancevich, \& Donnelly. 1985. Organisasi, Perilaku, Struktur, dan Proses. Jakarta: Bina Rupa Aksara.

Giroux, T. \& McLarney, C. 2014. Exploring the Leadership Continuum: The Relevance of Transformational Leadership on Organizational Performance. Proceedings of the Northeast Region Decision Sciences Institute, 862-886.

Jennex, M. 2006. Case Studies in Knowledge Management. Idea Group Publishing.

Jung, D.I., Chow, C., \& Wu, A. 2003. The Role of Transformational Leadership in Enhancing Organizational Innovation. The Leadership Quarterly 14, 525-544.

Katz, D. \& Kahn, R.L. 1978. The Social Psychology of Organizations. New York: Wiley. 
Katz, D. 1964. The Motivational Basis of Organizational Behaviour, dalam Behavior Science. 9, halaman: 131-133.

Kotter, John P. 1995. Leading Change, Menjadi Pioner Perubahan, (Joseph Bambang M.S., Penerjemah). Jakarta: PT Gramedia Pustaka Utama.

Laporan Road Map BPJS Ketenagakerjaan Tahun 2017-2021.

Mangkuprawira, Tb. Sjafri. 2009. Horison Bisnis, Manajemen, dan Sumber Daya Manusia. Bogor: ITB Press.

Naveed Ahmad Faraz, Chneng Yanxia, Fawad Ahmed, Zelalem Gebretsadik Estifo, Ali Raza. 2018. The Influence of Transactional Leadership on Innovative Work Behavior Mediation Model. European Journal of Business and Social Sciences, Vol. 07, No. 01.

Parmenter D. 2007. Key Performance Indicators Developing, implementing, and Using Winning KPIs. Hoboken, New Jersey: John Wiley \& Sons.

Porras, J.I. and Robertson, P.J. 1992. Organizational Development: Theory, Practice, and Research', in Dunnette, M. and Hough, L. (Eds). Handbook of Industrial and Organizational Psychology, 2nd ed., Vol. 3, pp. 720-822. Palo Alto, CA: Consulting Psychologists Press, Inc., Palo Alto.

Ramamoorthy, N., Flood, P.C., Slattery, T. and Sardessai, R. 2005. Determinants of Innovative Work Behavior: Development and Test of an Integrated Model. Creativity and Innovation Management, Vol. 14, No. 2, pp. 142-150.

Rensfelt A., Winblad C.J., Lindman L. 2008. KPI's Measuring and Evaluating in Order to Increase Logistic Efficiency, Vaxjo Universitet School of Management and Economics.
Bachelor Thesis G3 in Business Economics, 15 Logistics, FE3583, Spring Semester 2008.

Robbins dan Coulter. 1999. Manajemen, Edisi VI. PT Prehallindo.

Byars, Llloyd L. dan Rue, Leslie W. 2000. Human Resource Management, 8 edition. MCGraw-Hill.

Sadia Arif dan Aman Akram. 2018. Transformational Leadership and Organizational Performance. SEISENSE Journal of Management, Vol. 1, Issue 3, July 2018.

Samad. 2012. The Influence of Innovation and Transformational Leadership on Organizational Performance. Social and Behavioral Sciences, 57, 486-493.

Schuler, Randall dan Susan E. Jackson. 1997. Manajemen Sumber Daya Manusia, (Menghadapi Abad Ke-21). Jakarta: PT. Gelora Aksara Pratama.

Scott, S.G. and R.A. Bruce. 1994. Determinants of Innovative Behavior: A Path Model of Individual Innovation in the Workplace. Academy of Management Journal, 37, pp. 580-607.

Sugiyono. 2011. Metode Penelitian Kuantitatif, Kualitatif, dan R\&DD. Bandung: Afabeta.

Tanenhaus, M., Vinci, Chatelin, Y.M., dan Carlo, L. 2004. PLS Path Modeling. Computational Statistics and Data Analysis, 48: 159205.

Tichy Noel M. \& David O. Ulrich. 1984. The Leadership Challenge-A Call for the Transformational Leader. Sloan Management Review, Fall 1984, Vol. 26, No. 1, Reprinted with Permission.

Tierney, P. and Farmer, S.M. 2004. The Pygmalion Process and Employee Creativity", Journal of Management, Vol. 30, No. 3, pp. 413432. 
Timothy C. Bednall, Alannah E. Rafferty, 1 Helen Shipton, Karin Sanders, and Chris J. Jackson, 2018. Innovative Behaviour: How Much Transformational Leadership Do You Need?" British Journal of Management, Vol. 00, 1-21.

Voyce Li, Rebecca Mitchell, and Brendan Boyle. 2015. The Divergent Effects of Transformational Leadership on Individual and Team Innovation Group \& Organization Management. Group \& Organization Management. 1-32. sagepub.com/journalspermissions. nav.

Wang, H., Law, K., Hackett, R., Wang, D., \& Chen, Z.X. 2005. Leader-Member Exchange as a Mediator of the Relationship between Transformational Leadership and Followers' Performance and Organizational Citizenship Behavior. Academy of Management Journal, 48, 420-432.

Wang, E., Chou, H.-W., \& Jiang, J. 2005. The Impacts of Charismatic Leadership Style on
Team Cohesiveness and Overall Performance during ERP Implementation. International Journal of Project Management, 23, 173-180.

Werther, William B. \& Keith Davis. 1996. Human Resources and Personal Management. International Edition. USA: McGraw-Hill, Inc.

Xenikou, A. 2017. Transformational Leadership, Transactional Contingent Reward, and Organizational Identification: The Mediating Effect of Perceived Innovation and Goal Culture Orientations. Frontiers in Psycho$\log y, 8,1754$.

Yukl, Gary 1994. Leadership in Organizations. Terjemahan Jusuf Udayana. Kepemimpinan dalam Organisasi. Edisi 3. Jakarta: Penerbit Prenhallindo.

Yukl, Gary. 2005. Kepemimpinan dalam Organisasi (edisi V). Jakarta: PT Indeks.

Yukl. 2015. Kepemimpinan dalam Organisasi (Edisi VII). Jakarta: PT Indeks. 